\title{
Persuasive Strategy in Interactive Educational Games for Toddlers
}

\author{
Retno Purwani Sari \\ Fakultas Sastra \\ Universitas Komputer Indonesia \\ Bandung, Indonesia \\ retno.purwani.sari@email.unikom.ac.id
}

\author{
Cece Sobarna \\ Fakultas Ilmu Budaya \\ Universitas Padjadjaran \\ Bandung, Indonesia \\ cecesobarna@yahoo.com
}

\begin{abstract}
The aim of this study is to explain the persuasive language styles representing game play by focusing on: (1) the linguistic forms; and (2) the type of speech acts, designing a particular persuasive strategy. This study applied pragmaticstylistic perspectives along with a model analysis of Halliday's systemic functional grammar to answer the cognitive process of interpretation. Methodologically, analytic descriptive qualitative was adopted. As a result, this study finds the persuasive strategy is represented through direct and indirect speech acts to convey directive goals. Declarative, interrogative, explanative and imperative modes are recognized as demands that require toddlers' emotional response as well as involvement. Thus, interactive and active game play can be performed.
\end{abstract}

\section{Keywords—gameplay, language styles, persuasive strategy}

\section{INTRODUCTION}

Digital technology changes our learning behavior. Such a learning method using games, experiences gradual transformation; the games adopt technological development. As well as a play apparatus, they are treated as a media for learning social values. They become social medium conveying concepts, ideologies, and advocacy aimed to population responding better to interactive media (children, teenagers, and a growing population who play games) Games are employed to educate this population[1].

The use of interactive educational games itself is a response to growing popularity of digital technology. Specifically, toddlers - children who inherently love playing - are easily attracted by games. They facilitate toddlers' needs and pleasures apart from considering moral values. Recent researches are confirming that innovation stimulating children's emotions are required to encourage children learning [2-3]. In this case, game designs are intended to control toddlers behaviors and acts persuasively. Focusing to the ideas, educational games are considered as a persuasive technology.

With persuasive characters, the educational games are designed. The elements of story (gameplay, writing, audio design, environment art, and animation) are considered when game designers create their game designs. As games are the set of players' activities, gameplay develops game design interactively. In other words, good games design providing appropriate gameplay promote goals that can stimulate its players to decide a specific movement and to pursue an expected achievement. Thus, gameplay acts as a significant function in creating a good game design[4].

As the idea of gameplay is a feature of players' active participation as a response, the gameplay is constructed by a sequence of instructions leading players to make choices and to do actions. In linguistic field, the instructions are manifested through the choice of performative verbs[5]. The verbs are used for performing actions. Simply, the gameplay is a process of "verbing". These verbs construe gameplay's attitude toward players, giving emotive feelings and clues of limitation (things a player can and cannot do). This rule brings a basic function of gameplay[6].

The players engage rule structures. They experience imaginative exploration in the game world where they learn moral values to achieve maturity through their own experiences in reacting to problems and learning the wisdom. In this sense, they learn the values with fun and unconsciously. The sequence of actions results in an effect that may earn a pleasant reward. Since the fun feeling is crucial in educational game, the rule structures should be managed carefully, considering player's esteem and pride as well as their language competence and language competence.

Considering the issues, the hypothesis is formulated by debating that certain communicative strategies are implemented to meet persuasive functions. The way in which persuasive strategies are designed, the type of persuasive strategies is applied, and the language style that is chosen from the range of various valuable forms, are observed to examine linguistic contribution to gameplay of interactive education game. The aim of this study is to provide persuasive linguistic models that can be adopted in designing gameplay of an interactive educational game. These models potentially promote the language choices to Indonesian game designers who engage themselves in social movement; formulating national identity through developing children's moral maturity that can be measured from their actions.

Effective power determines the language use for controlling the other party's actions, the interest in the way in which language conveys persuasive function began to turn away from psycholinguistic concerns with children language acquisition to focus on contextual situated learning[7]. Contextual situated motivating language socialization and the acquisition of discourse when issues of power and control encountered communicative conflicts [8]. Strategies covering conflict negotiation and resolution. Considering the conflict negotiation and resolution, Johnstone has claimed that certain styles correlate with certain persuasive strategies: quasilogic, presentation and analogy [9-10]. The observation of the chosen linguistic forms. Blakenship debated that language styles participated in persuasion [11]. The broad correspondence between "control acts", effective power, contextual situated, strategies, and style initiated the study of persuasive strategy in children literature as a medium of social movement [12]. The fact that genre and addressee's 
characters determine the choice of persuasive strategy, motivate us to conduct this study; proving that the choice of language style correlates to the genre and addressee's character s, and providing a persuasive linguistic models for game design.

In this article, this study explores factors influencing the choice of persuasive strategy and language styles involving the moods and speech acts. These features propose an effective stimulation to motivate toddlers' emotion. The persuasive strategy along with language styles offers the way language control players' action.

As a support empirical research, analytic descriptive method is suggested to explain the phenomena and issues triggering the choice of strategy and language styles. We implemented closed reading as a technique of collecting data and descriptive techniques for analyzing data. Some related theories are adapted to explain data characteristics.

\section{METHOD}

\section{A. Genre of Data Source, Data Indicators, and Hypothesis}

Applying analytic descriptive qualitative method, the study was conducted on data taken from two interactive educational games published by Riri Story books, one of Eduka Studio branches [13-14].

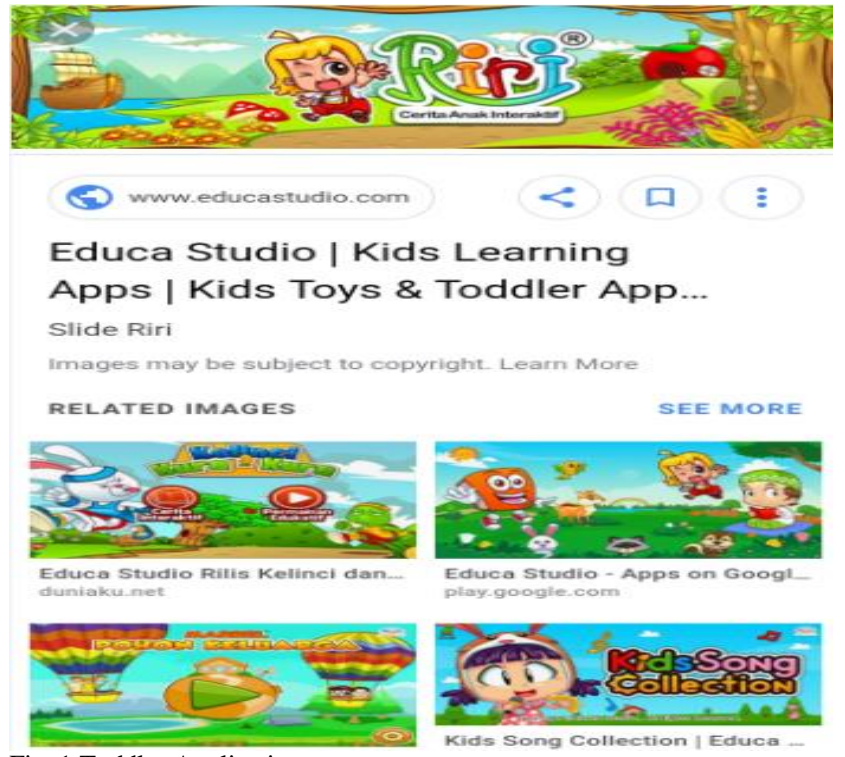

Fig. 1 Toddler Application.

The games (Bawang Merah Bawang Putih and Kelinci \& Kura-kura) were designed for toddlers ( $1-3$ years old) as kid toys and toddler application, published online and can be downloaded for free. These games offer digital story books as an alternative of print book; making reading activities more fun for toddlers.

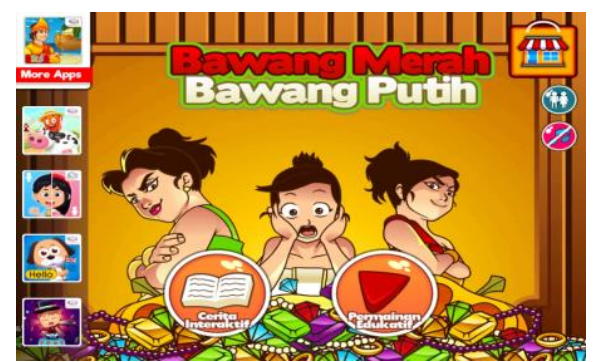

Fig. 2 Interactive Educational Games (a)

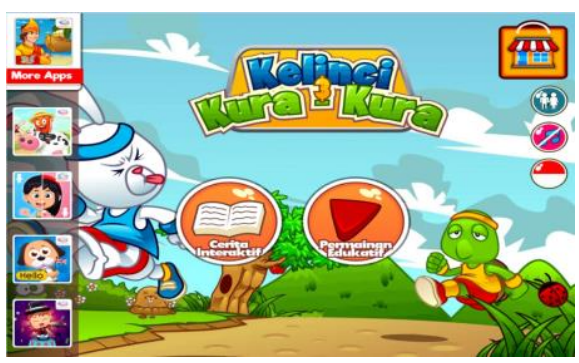

Fig. 2 Interactive Educational Games (b)

The game design of those illustrates the adaptation of player characters, player-centric design. The focus is to accomplish missions such as mismatch, counting, guessing animals, learning colors and shape. In these activities, toddlers learn to make a decision. The reading as a main intellectual activity can be executed by players (toddlers) or they can listen to the audio. A multi-sensory activity entails perceptual, cognitive and motoric interactions [1]. In these games, stories are built through gameplay, writing, environment art, and audio design. The elements of the game stories adjust toddlers' mental characters: they explore on how the things work and on how they are supposed to respond the world [15].

In this study, data are identified as language expressions (in clause constructions) representing instructions that initiate gameplay. The indicators of data were determined based on: (1) the clause types constructing instructions; (2) types of mood conveyed; and (3) expressions showing compliment after executed actions. The hypotheses are examined through those indicators. The choice of language styles is determined by players' characteristics and contextual situated, and the choice determine the persuasive strategy implemented in these games.

\section{B. Adapted Theories}

Related theories are adapted to explain the phenomena and characteristics of data selected. This study adopted Clark's pragmatic-stylistic perspectives which discuss interpretation of language choices as the source of meaning for understanding [16]. Language styles considered as a choice of speakers (game designers represented by gameplay) are discussed in stylistic perspective. These styles bring certain effects on players' attitudes. In order to describe the process of interpretation, called inferences, pragmatic rules are used. Halliday and Matthiessen's ideas offered comprehensive analysis model to explain the process of inferences since this study dealt with language functions [17].

\section{RESULTS}

In the games used, interactive activities are classified into two main ones: (1) interactive story with reading as a focus; and (2) educative plays with four different activities (guessing picture/animals/name, counting, puzzle for learning shape, and dress up for learning color). The gameplay shows the limitation players have (things can and cannot do) through the choice of performative verbs. The verbs convey players' 
ability that they can explore. The meaning of 'ability' is supported by circumstances constructed by other elements of story (environment art, audio and writing). The indicators used in this sense are laws of nature and social laws [18-19]. The players play as an actor of the event actualization. They manage themselves to make the event happen. The meaning of 'necessity' comes from players themselves with laws of nature and social laws as power.

In this study, gameplay begins with "verbing" and ends with feedback; verbing - action - effect - appreciation as a feedback. The verbing initiates the players' actions. Based on the data, clauses are constructed by verbal groups with base forms taken for verbing and nominal groups. Data make the subjects implicit in grammatical structure. The subjects are referred to the players themselves.

Data are classified based on: (1) type of activities; (2) the elements constructing the clauses; (3) role in exchange; (4) types of moods. The data classification is shown in TABLE I.

TABLE I. DATA CLASSIFICATION

\begin{tabular}{|c|c|c|c|c|c|c|}
\hline \multirow{3}{*}{ Acts } & \multicolumn{6}{|c|}{ Language Expressions } \\
\hline & \multirow[b]{2}{*}{ Clauses } & \multicolumn{2}{|c|}{ Elements } & \multirow[b]{2}{*}{ Adj } & \multirow{2}{*}{$\begin{array}{l}\text { Roles } \\
\text { in ex- } \\
\text { change }\end{array}$} & \multirow{2}{*}{$\begin{array}{c}\text { Types } \\
\text { of } \\
\text { moods }\end{array}$} \\
\hline & & $\begin{array}{c}\text { Verbal } \\
\text { Groups }\end{array}$ & $\begin{array}{c}\text { Nominal } \\
\text { Groups }\end{array}$ & & & \\
\hline $\begin{array}{l}\text { Verb } \\
\text { - ing }\end{array}$ & $\begin{array}{l}\text { Cerita } \\
\text { interaktif }\end{array}$ & - & $\sqrt{ }$ & - & $\begin{array}{c}\text { Receiv } \\
\text {-ing }\end{array}$ & $\begin{array}{l}\text { Decla } \\
\text { rative }\end{array}$ \\
\hline 2 & Otomatis & - & - & $\sqrt{ }$ & $\begin{array}{c}\text { Receiv } \\
\text {-ing }\end{array}$ & $\begin{array}{l}\text { Decla } \\
\text { rative }\end{array}$ \\
\hline 3 & Baca sendiri & $\sqrt{ }$ & - & - & $\begin{array}{c}\text { Receiv } \\
\text {-ing }\end{array}$ & $\begin{array}{l}\text { Impe- } \\
\text { rative }\end{array}$ \\
\hline 4 & $\begin{array}{l}\text { Pilih } \\
\text { halaman }\end{array}$ & $\sqrt{ }$ & - & - & $\begin{array}{c}\text { Receiv } \\
\text {-ing }\end{array}$ & $\begin{array}{l}\text { Impe- } \\
\text { rative }\end{array}$ \\
\hline 5 & $\begin{array}{l}\text { Pilih } \\
\text { permainan }\end{array}$ & $\sqrt{ }$ & - & - & $\begin{array}{c}\text { Receiv } \\
\text {-ing }\end{array}$ & $\begin{array}{l}\text { Impe- } \\
\text { rative }\end{array}$ \\
\hline 6 & $\begin{array}{l}\text { Tebak } \\
\text { gambar }\end{array}$ & $\sqrt{ }$ & - & - & $\begin{array}{c}\text { Receiv } \\
\text {-ing }\end{array}$ & $\begin{array}{l}\text { Impe- } \\
\text { rative }\end{array}$ \\
\hline 7 & $\begin{array}{l}\text { Hitung } \\
\text { benda }\end{array}$ & $\sqrt{ }$ & - & - & $\begin{array}{c}\text { Receiv } \\
\text {-ing }\end{array}$ & $\begin{array}{l}\text { Impe- } \\
\text { rative }\end{array}$ \\
\hline 8 & $\begin{array}{l}\text { Puzzle } \\
\text { bentuk }\end{array}$ & - & $\sqrt{ }$ & - & $\begin{array}{l}\text { Receiv } \\
\text {-ing }\end{array}$ & $\begin{array}{l}\text { Decla } \\
\text { rative }\end{array}$ \\
\hline 9 & Dress up & $\sqrt{ }$ & - & - & $\begin{array}{c}\text { Receiv } \\
\text {-ing }\end{array}$ & $\begin{array}{l}\text { Impe- } \\
\text { rative }\end{array}$ \\
\hline 10 & Berhitung & $\sqrt{ }$ & - & - & $\begin{array}{c}\text { Receiv } \\
\text {-ing }\end{array}$ & $\begin{array}{l}\text { Impe- } \\
\text { rative }\end{array}$ \\
\hline 11 & $\begin{array}{l}\text { Bermain } \\
\text { puzzle } \\
\text { bayangan }\end{array}$ & $\sqrt{ }$ & - & - & $\begin{array}{c}\text { Receiv } \\
\text {-ing }\end{array}$ & $\begin{array}{l}\text { Impe- } \\
\text { rative }\end{array}$ \\
\hline 12 & $\begin{array}{l}\text { Tebak } \\
\text { hewan }\end{array}$ & $\sqrt{ }$ & - & - & $\begin{array}{c}\text { Receiv } \\
\text {-ing }\end{array}$ & $\begin{array}{l}\text { Impe- } \\
\text { rative }\end{array}$ \\
\hline 13 & $\begin{array}{l}\text { Bermain } \\
\text { tebak } \\
\text { gambar }\end{array}$ & $\sqrt{ }$ & - & - & $\begin{array}{c}\text { Receiv } \\
\text {-ing }\end{array}$ & $\begin{array}{l}\text { Impe- } \\
\text { rative }\end{array}$ \\
\hline 14 & Tebak nama & $\sqrt{ }$ & - & - & $\begin{array}{c}\text { Receiv } \\
\text {-ing }\end{array}$ & $\begin{array}{l}\text { Impe- } \\
\text { rative }\end{array}$ \\
\hline 15 & $\begin{array}{l}\text { Menyusun } \\
\text { huruf }\end{array}$ & $\sqrt{ }$ & - & - & $\begin{array}{c}\text { Receiv } \\
\text {-ing }\end{array}$ & $\begin{array}{l}\text { Impe- } \\
\text { rative }\end{array}$ \\
\hline 16 & Exit & $\sqrt{ }$ & - & - & $\begin{array}{c}\text { Receiv } \\
\text {-ing }\end{array}$ & $\begin{array}{l}\text { Impe- } \\
\text { rative }\end{array}$ \\
\hline 17 & install & $\sqrt{ }$ & - & - & $\begin{array}{c}\text { Receiv } \\
\text {-ing }\end{array}$ & $\begin{array}{l}\text { Impe- } \\
\text { rative }\end{array}$ \\
\hline 18 & $\begin{array}{l}\text { Permainan } \\
\text { edukatif }\end{array}$ & - & $\sqrt{ }$ & - & $\begin{array}{c}\text { Receiv } \\
\text {-ing }\end{array}$ & $\begin{array}{l}\text { Decla } \\
\text { rative }\end{array}$ \\
\hline 19 & $\begin{array}{l}\text { Berapakah } \\
\text { jumlah } \\
\text { bunglon? }\end{array}$ & Comp & te clause & - & $\begin{array}{l}\text { Receiv } \\
\text {-ing }\end{array}$ & $\begin{array}{l}\text { Inter- } \\
\text { rogati } \\
\text { ve }\end{array}$ \\
\hline 20 & $\begin{array}{l}\text { Yang } \\
\text { manakah } \\
\text { gambar }\end{array}$ & Comp & te clause & - & $\begin{array}{l}\text { Receiv } \\
\text {-ing }\end{array}$ & $\begin{array}{l}\text { Inter- } \\
\text { rogati } \\
\text { ve }\end{array}$ \\
\hline
\end{tabular}

\begin{tabular}{|c|l|c|c|c|c|c|}
\hline \multirow{2}{*}{ Acts } & \multirow{5}{*}{ Clauses } & \multicolumn{2}{|c|}{ Language Expressions } \\
\cline { 2 - 7 } & $\begin{array}{c}\text { Verbal } \\
\text { Groups }\end{array}$ & $\begin{array}{c}\text { Nominal } \\
\text { Groups }\end{array}$ & Adj & $\begin{array}{c}\text { Roles } \\
\text { in } \text { ex- } \\
\text { change }\end{array}$ & $\begin{array}{c}\text { Types } \\
\text { of } \\
\text { moods }\end{array}$ \\
\hline \multirow{2}{*}{$\begin{array}{c}\text { Feed } \\
\text { back }\end{array}$} & Luar biasa & - & $\sqrt{ }$ & - & Giving & $\begin{array}{c}\text { Excla } \\
\text { mati- } \\
\text { ve }\end{array}$ \\
\hline 22 & Hebat & - & $\sqrt{ }$ & - & Giving & $\begin{array}{c}\text { Excla } \\
\text { mati- } \\
\text { ve }\end{array}$ \\
\hline 23 & Bagus & - & $\sqrt{ }$ & - & Giving & $\begin{array}{c}\text { Excla } \\
\text { mati- } \\
\text { ve }\end{array}$ \\
\hline 24 & Pintar & - & $\sqrt{ }$ & - & Giving & $\begin{array}{c}\text { Excla } \\
\text { mati- } \\
\text { ve }\end{array}$ \\
\hline
\end{tabular}

\section{DISCUSSION}

Our results show that verbing in the first process of constructing gameplay indicates the use of minor clauses [17]. The clauses are built by verbal group without thematic structure. Data 1.(3), for example,

\section{1.(3) Baca sendiri \\ read self \\ 'read by yourself'}

The theme of the structure, also the subject of the clause, is omitted in grammatical structure of the clause 1.(3). The theme and subject of the clause are understood as 'you' that refers to toddler as a player. The actor of the action can be interpreted using contextual features of the discourse. Games provide discourse with actions intended to ask players 'doing' actions [5].

In the perspective of systemic functional grammar [17], the verb baca construes a process of material. It brings about the change conducted by the actor 'you'. 'You', referring to the player, has 'ability' to make a change. He is convinced through the evidence of his own characteristics. As an animate with power, he has ability to do the action.

With the realm of games, contextual situated is built through the certain conditions $[1,4]$. The action will result in a specific effect and the effect will gain a feedback that is a reward. In these games, reward is identified as compliment. The compliment such as bagus 'good' luar biasa 'excellent' shows positive evaluation for the player's action. This positive action potentially increases player's self-esteem [7]; he feels good with what he has done.

The exclamative clauses bagus and luar biasa, as representatives, initiate the player to do the next directive goal of imperative clause data 1.(3) Baca sendiri. 'Control act' is conducted persuasively by giving positive evaluation. In this sense, the control act is identified as task-centered control acts, that is, the control is intended to player to accomplish what he has been asked. Since the directive function is expressed directly in imperative clause, direct speech acts is used to present persuasive strategy.

Different from imperative clause data 1.(3) Baca sendiri, exclamative clause data 2.(3) shows another case of persuasive strategy.

\section{2.(21) Luar biasa out common}


'excellent'

The clause of data 2.(21) expresses expressive to show appreciation in order to control the next action. It utters to make directive goal implicit in its structure. The clause not only functions to express appreciation but also to control player's action. Indirect speech acts is chosen to present persuasive strategy.

Data 3.(1) Cerita interaktif is a minor clause with no thematic structure.

\section{3.(1) Cerita interaktif \\ story interactive \\ 'Interactive story'}

It may be interpreted as a discourse; the story can be considered as interactive if there is interaction between the story and the player acting as a reader [1]. Player as a communicative participant is invited to get involved in the interaction. As a responsible party, player takes a part in the interaction and decide an appropriate action as a respond of the utterance of data 3.(1). Since data 3.(1) is positioned as an opposite of data 4.(5) pilih permainan, data 3.(1) is interpreted as an alternative action that had to be chosen.

\section{4.(5) pilih permainan}

choose game

'choose the game (to play)'

Data 3.(1) controls player's action indirectly. Directive goal is expressed implied from the structure of utterance. Indirect speech acts is chosen to persuade the player. Meanwhile, data 4.(5) expresses the directive goal directly. Direct speech acts is chosen to present persuasive strategy.

Beside declarative, exclamative and imperative clause in minor structure, interrogative clause with thematic structure manifest persuasive strategy with indirect speech acts. The directive goal implies in the clause structure of data 5.(19)

\section{5.(19) Berapakah jumlah bunglon}

Many particle number chameleons

How many chameleons are there?

Particle $-k a h$ bahasa Indonesia in interrogative structure makes the preceded word berapa prominent [20]. The prominence is given to the word berapakah in order to get player's attention. He is persuaded to focus on the word and make a decision based on the word.

Considering the results of this study, the persuasive strategy is focused on the involvement of the player and offers a satisfaction of desire. The presentation strategy is chosen in the interactive educational game for toddlers. The instructions themselves are dominantly presented in minor clauses with no thematic structure. However the theme and subject are understood as 'you' that refers to the player himself. These minor clauses are chosen to give direct instruction to players (toddlers). Toddlers are people with limited language expressions [15]. They are in the level of language acquisition. In this case, simple expressions are more effective than complex ones. Moreover, the development of maturity of toddlers is considered in choosing direct speech acts, building conflict negotiation as a strategy. However, persuasive strategy is still maintained using positive evaluation.

The use of imperative moods indicates that simple instructions are given to avoid conflict. When declarative, interrogative and exclamative used, emotion participate in the process. Since politeness is not the issue, imperative clauses do not lead to impolite. Face threatening is not considered. The focus is not the politeness but the doing of the actions [1, 5].

\section{CONCLUSION}

Contextual situated determines a persuasive strategy applied. In this study, presentation strategy is represented through declarative, interrogative, exclamative and imperative for controlling players' actions. The directive goal is presented directly and indirectly. According to data analysis, the utterance goals are dominantly expressed directly. The results are triggered by the genre of data sources, players' characteristics and utterance function.

\section{ACKNOWLEDGMENT}

This study was funded by Universitas Komputer Indonesia. We would like to thank all the scholars who have shared new perspectives to the development of this study, and the institution supporting this study with the amount of fund. In addition, we thank to the scholars who have reviewed the first manuscript until gaining the significant improvement.

\section{REFERENCES}

[1] V. Rao, "How to Say Things with Actions I: a Theory of Discourse for Video Games for Change," IEEE Transl. J. Think Design Play. Netherlands, pp. 1 - 17, September 2011.

[2] N. Mikkelson, "Powerful Magic Learning from Children's Response to Fantasy Literature," USA: Teachers' College Press, 1997.

[3] W. Syakira Meor Hissan, "An Analysis of the Children's Characters in Roald Dahl's Novel: Charlie and The Chocolate Factory," Indonesia Journal of Applied Linguistic, Vol. 2(1), pp. 83 - 92, July 2012.

[4] B. Brathwaite, and I. Schreiber, "Challenges for Game Designers," USA: Course Technology, a part of Cengage Learning,2009.

[5] S. Domsch, "Storyplaying: Agency and Narrative in Video Games," Germany: Walter de Gruyter GmbH, 2013.

[6] D. Robinson, "Introducing Performative Pragmatics," NY: Routledge, 2006.

[7] S. Ervin-Tripp, M.C. O’Connor, and J. Rosenberg, "Language and Power in the Family," in M. Schulzan and C.K. Ramerate (eds), Language and Power, CA: SAGE, pp. 116-135, 1984.

[8] J. Cook-Gumperz, and A. Kyratzis, "Child Discourse," in D. Schiffrin, D. Tannen, and H.E. Hailton (eds.) The Handbook of Discourse, USA: Blackwell Publisher Ltd., pp. 590 - 611, 2001.

[9] C. Kakava, "Discourse and Conflict," in D. Schiffrin, D. Tannen, and H.E. Hailton (eds.) The Handbook of Discourse, USA: Blackwell Publisher Ltd., pp. 650-670, 2001.

[10] B. Johnstone, "Linguistic Strategies and Cultural Styles for Persuasive Discourse," in S. Ting-Toomey and F. Korzenny (eds.), Language, Communication, and Culture: Current Dirrections, CA: SAGE, pp. 139 $-156,1989$.

[11] K.L. Blakenship, "Linguistic Power and Persuasion: An Analysis of Various Language Style," Dissertation Manuscript. M.A. Ball State University, 2001.

[12] R. P. Sari, C. Sobarna, E.T.S. Sujatna, and N. Darmayanti, "Persuasive Strategies in the Utterances of English Children's Stories: A Study of Pragmastylistics," Dissertation Manuscript. Universitas Padjadjaran, 2018.

[13] Eduka Studio (Startup),"Bawang Merah Bawang Putih (Mobile Games), Malang, Indonesia: Riri Story Books. 2013

[14] Eduka Studio (Startup),"Kisah Kelinci dan Kura-kura (Mobile Games), Malang, Indonesia: Riri Story Books, 2013. 
[15] P. A. Potter, and A.G. Perry, "Fundamental of Nursing," $6^{\text {th }}$ Edition, USA: Mosby, 2004.

[16] B. Clark, "The Place Near the Thing Where We Went That Time: An Inferential Approach to Pragmatic Stylistics," in Paper: Topic in Language 3, University of Constatine the Philosopher, Nitra, pp. 1 30, 2009.

[17] M.A.K. Halliday, and C.M.I.M Matthiessen, "An Introduction to Functional Grammar," Great Britain: Arnold, 2004.
[18] H. Alwi, "Modalitas dalam Bahasa Indonesia," Yogyakarta: Kanisius, pp. 163, 1992

[19] R. Quirk et al, "A Comprehensive Grammar of the English Language," London: Longman, pp. 219 - 237, 1985.

[20] Kemendikbud, "Kamus Besar Bahasa Indonesia versi Online/daring," 